\title{
PRACTICAL APPLICATION OF SURVEYING METHODS FOR DETERMINATION OF VOLUME QUARRY MINING
}

\author{
Celms Armands ${ }^{1}$, Pukite Vivita ${ }^{1}$, Reke Ilona ${ }^{1}$, Balevičius Giedrius ${ }^{2}$, Ozolina Sandija ${ }^{3}$ \\ ${ }^{1}$ Latvia University of Life Sciences and Technologies, ${ }^{2}$ Vytautas Magnus University \\ Agriculture Academy, ${ }^{3}$ "Metrum" Ltd
}

\begin{abstract}
Nowadays, various types of geodetic measuring instruments are available in surveying. When conducting a survey of a terrain, surveyor must choose a survey method that is capable of providing high precision measurements. In the surveying process, it is possible to use the following measurement methods - tachymetric survey method, positioning method and remote sensing method. Each of the methods produces data formats that can be used further for volume calculations.

The paper analyses the volume differences that are obtained when using various survey methods and volume calculation programs to obtain the surface model. The use of such a tool is important for useful mineral miners, so that surveyors make qualitative surveys and obtain accurate and reliable volumes.

Useful minerals miners are required to report annually on their mining volume for a specified period. The useful minerals miners shall at all times keep records of the quantities of minerals actually extracted. Regardless of the type of accounting, topographic surveying and the calculation of volumes, if mineral is extracted in mineral deposits of national importance, more than $50000 \mathrm{~m}^{3}$, are required (Augstas detalizācijas topogrāfiskās..., 2012). High-quality and accurate topographic survey is needed to create the most realistic surface model appropriate to the terrain. It is defined that the difference between the volumes obtained from the recording of vehicle loads should not be more than $5 \%$ when comparing the result of the mineral extraction from topographic surveys (Derīgo izraktenu ieguves..., 2012; Noteikumi par valsts..., 2018).

Nowadays, various measurement methods can be used to obtain data from which a surface model can be generated, and this model can then be used for volume calculations. The surface model is a set of points where, in addition to plane coordinates ( $\mathrm{x}$ and $\mathrm{y}$ ), there is also altitude (z) known (Luukkonen, 2011). Each measurement method has its own different measuring instruments that can be used, each method has its own operating principles, on which the quality and accuracy of the obtained data depends.

Key words: Quarry mining, tachymetric surveying methods, GNSS, remote sensing, surface model.
\end{abstract}

\section{Introduction}

Nowadays, various measurement methods can be used in order to obtain data set from which a surface model can be generated. Surface model is a set of points, where in addition to coordinates of the horizontal plane (x and y), also component of altitude $(\mathrm{z})$ is known (Luukkonen, 2011). In order to obtain a surface model, various measurement methods can be applied. In connection to importance of useful minerals in the economics of the state in general, it is important to carry out accurate measurement of their volumes. For each measurement method diverse measurement instruments shall be used, each method has its own operating principles. Quality and accuracy of obtained data depend on them.

Measurement here is a set of geodetic works, which result in obtaining of data necessary for compiling of plans, maps and profiles. They are lengths of lines, angles and altitudes of points. According to aim of a measurement, vertical, horizontal and topographic measurement is distinguished.

There is need to perform a topographic measurement in terrain, in order to obtain data on situation in terrain and marks of altitude. In the paper, authors view three different measurement methods:

1. Tachymetric measurement method;

2. Global positioning method;

3. Remote sensing method.

Regulations No. 281 of the Cabinet of Ministers of the Republic of Latvia "Regulations on topographic information of high detail and its central database" (Augstas detalizācijas topogrāfiskās..., 2012) determine procedure, in which topographic measurement of objects shall be performed. Regardless of the measurement method, surveyor shall perform topographic measurement in geodetic coordinate system of Latvia of year 1992- LKS 92. It is expressed in plane coordinates of Mercator transversal projection. In the territory of the Republic of Latvia, European Vertical reference system is realized. Height system in Latvia is normal height system epoche 2005,5 - LAS-2005,5 (G̣eodēziskās atskaites 
sistēmas..., 2011). When the measurement works are performed, surveyors shall use geodetic instruments, for which controls are performed and which complies with accuracy requirements set by manufacturers (Matos, Goncalves, 2003).

When a topographic measurement is performed in terrain, it is possible to use beforehand obtained topographic information on the given territory. If measurement in the territory in question is performed repeatedly, it is determined that difference of coordinates and altitudes shall not exceed $-30 \mathrm{~cm}$ for coordinates in horizontal plane and $20 \mathrm{~cm}$ for component of altitudes for contours and objects of the situation, which are not explicit. In a terrain with explicit contours and objects, requirements are $5 \mathrm{~cm}$ for coordinates in horizontal plane and $3 \mathrm{~cm}$ for altitude components (Derīgo izraktenu ieguves..., 2012; Noteikumi par valsts..., 2018).

In the process of application of measurement methods, for the calculation of volumes of quarrying, specialized software is used, where it is possible to perform calculations of volumes of various types. As it is determined in the Regulations No. 570 of the Cabinet of Ministers of the Republic of Latvia "Procedure of mining and quarrying", in necessary requirements for mining and quarrying and accounting of useful minerals, if miner of the useful mineral wins more than $50000 \mathrm{~m}^{3}$, regardless of the type of accounting it is necessary to ensure topographic measurement, as well as calculation of volumes acquired within calendar year.

Result of calculation of volumes of minerals depends on the accuracy of the obtained surface model that is used as the base for calculation of obtained volumes. When topographic measurement of location of useful minerals is performed, in various periods of time, difference of results of volumes shall not be greater than $5 \%$ of results, where accounting is performed according to vehicle cargos. Surveyor, when he carries out topographic measurement and uses some measurement method shall obtain data volume of high quality as possible, because only from field data of high quality it is possible to obtain accurate and plausible surface model. It is possible, if field measurements are performed complying with method for obtaining of measurement data as accurate as possible. This applies to application of any measurement for the obtaining of surface model.

When authors worked with this research, purpose of the work was set - to study differences of volumes of mining of quarries by use of diverse measurement methods. In order to achieve the purpose of the research, work tasks were set as follows:

1. Description of the quarry of mining of useful minerals;

2. Applied measurement methods, when quarry was measured, in different periods;

3. Usage of obtained geospatial data in the determining of volumes of mining of useful minerals;

4. Analysis of results and proposals.

Materials of the research could be used in surveying enterprises that deal with improvement of methodology of accounting of volume of extraction of minerals.

\section{Methodology of research and materials}

For the comparison and control of extracted volumes of useful minerals, surveyor performs measurement of territory of quarries in order to calculate volume from the obtained measurement data. In the research, measurement of the territory of the quarry "Akmenscucinas" of the dolomite deposit "Iecava" (Fig. 1).

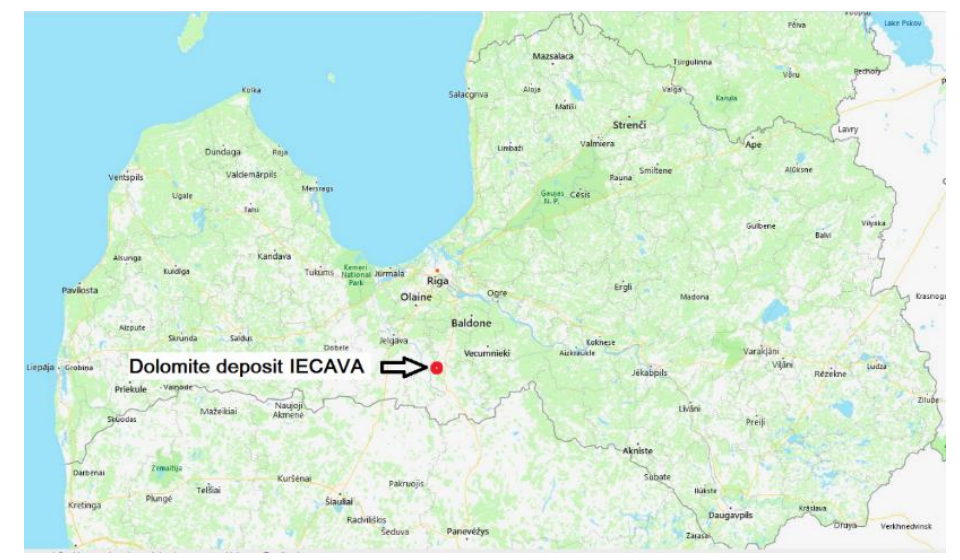

Fig. 1. Location of the quarry "Akmenscucinas" of the dolomite deposit "Iecava" in Latvia. 
In the quarry "Akmenscucinas", field measurements were performed by three different measurement methods. Further the obtained measurement data were processed by volume calculation software "Virtual Survey" and "Bentley Microstation Powersurvey V8i".

Owner of the quarry "Akmenscucinas" of the dolomite deposit "Iecava" is state joint stock company "Latvijas autocelu uzturetajs" that manages the quarry. License for subsoil use is assigned to state joint stock company "Latvijas autocelu uzturetaājs", where is defined that in deposit "Iecava", useful mineral dolomite in the time period from year 2014 until 2039 can be extracted. The quarry is located about 9 $\mathrm{km}$ to southwest from Iecava and about $27 \mathrm{~km}$ to southeast from Jelgava. The total limit of extraction in dolomite deposit "Iecava" is set 2206.13 thousand $\mathrm{m}^{3}$.

In the course of realization of the research, three different measurement methods for the registration of volume of extraction of the quarry were used - tachymetric measurement method, GNSS positioning method and remote sensing method (use of unmanned aircraft).

Tachymetric measurement method. In the measurement method, electronic tachymeter Leica TCR805power was used. For performance of measurement works, points of support geodetic network were installed. Coordinates for support network points were obtained by measurement by use of GNSS receiver set Leica GX1230. When tachymetric measurement was conducted, fixations of the measurements were performed so that it would possible to characterize the surfaces of the quarry at the given moment as close as possible.

GNSS positioning method. When positioning method was applied, GNSS receiver Leica GX1230 was used. In measurement by GNSS method, eventual adverse effects of multiple signal reflection in the specific location, as well as other factors affecting the accuracy shall be considered. Before the performance of measurements, planning works were carried out in order to obtain availability of optimal number of satellites and optimal position in the selected location and at the selected time. Measurement was performed in Real Time Kinematic (RTK) mode, in framework of LatPOS base support system. When GNSS RTK measurement was conducted, fixations of the measurements were performed so that it would possible to characterize the surfaces of the quarry at the given moment as close as possible.

Remote sensing method. In the realization of this method, unmanned aircraft DJI Phantom4 with photogrammetric camera was used. As the quarry was measured several times, each time before the performance of the flight, ground control points (GCP Plates $(40 \times 40 \mathrm{~cm})$ ) were placed in homogenous manner. GCP were measured in every measurement session and linked to the defined coordinate and height systems in Latvia. Such approach ensured measurement of the surface of the quarry in unified spatial reference system and enabled to calculate correctly the volumes of extracted deposits (Bosas et al., 2013). Height of the flight in the measurement process was set to $50 \mathrm{~m}$, as well as coverage of photography during the flight was defined, the frontal coverage $-80 \%$, the lateral coverage $-70 \%$ (Digitālā virsmas modela..., 2014; Lukss, 2017).

Measurement campaigns in the quarry "Akmenscucinas" of the dolomite deposit "Iecava" in 2018 were organized three times (Table 1).

Table 1

Measurement methods and time of performance

\begin{tabular}{|l|c|c|c|}
\hline \multirow{2}{*}{ Measurement method } & \multicolumn{3}{|c|}{ Year 2018 } \\
\cline { 2 - 4 } & July & October & December \\
\hline Tachymetric measurement method & $\checkmark$ & $\checkmark$ & $\checkmark$ \\
\hline GNSS positioning method & $\checkmark$ & $\checkmark$ & $\checkmark$ \\
\hline Remote sensing method & $\checkmark$ & $\checkmark$ & $\checkmark$ \\
\hline
\end{tabular}

By methods described above, models of surface of the quarry on specific date were obtained. By use of the surface models obtained, it was possible to perform calculation of volumes of extracting of useful minerals. Principle of calculation of volume of extraction of useful minerals is based on the obtained surfaces on different dates of measurement (Jawecki et al., 2019; Kubodera et al., 2017). Body is obtained in the result, volume of which characterizes volume of extraction of useful mineral between two dates of measurement. (Fig.2). 


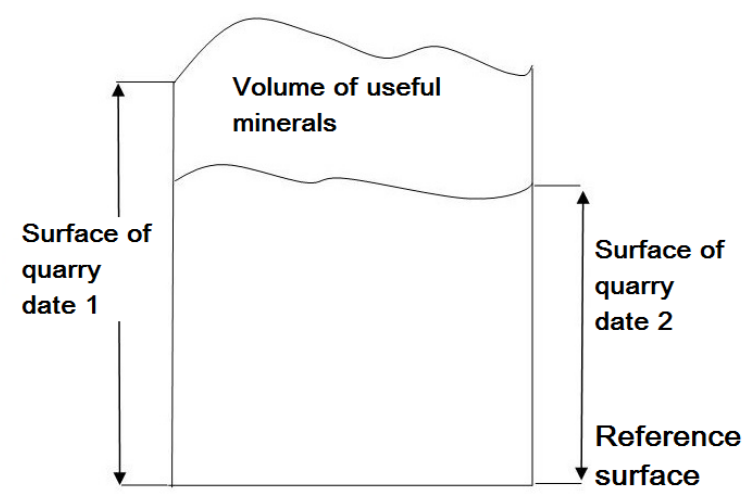

Fig. 2. Principle of calculation of volume of useful mineral

\section{Discussions and results}

The applied surface measurement methods give the necessary data, from which it is possible to create surface model. The obtained data further were calculated by use of geospatial software package "Virtual Survey" and "Bentley Microstation Powersurvey V8i". Hence, from data of each measurement method, surface models were obtained by use of both geospatial packages.

In July 2018, first measurement stage of the quarry was organized. In this case, situation to be measured in the terrain was before extracting of useful mineral, consequently the surface was without sharp changes of relief. Obtained average elevation difference between GNSS positioning and tachymetric measurement method is $1-2 \mathrm{~cm}$, in some places up to $5 \mathrm{~cm}$. Elevation differences between measurement methods can be explained with the fact that surveying rod was placed in different places. Horizontal and vertical accuracy of measurements of GNSS positioning method was not worse than $1 \mathrm{~cm}$. Such accuracy was observed also in measurement cycles of October and December. If we compare the obtained elevation values between remote sensing and GNSS positioning/tachymetric measurements, we can see that the difference of elevations is up to $3 \mathrm{~cm}$.

According to data of results of the applied measurement methods, surface models in the software environment "Virtual Survey" and "Bentley Microstation Powersurvey V8i" were obtained. In Fig. 3, surface model according to data obtained by DJI Phantom4 is shown.

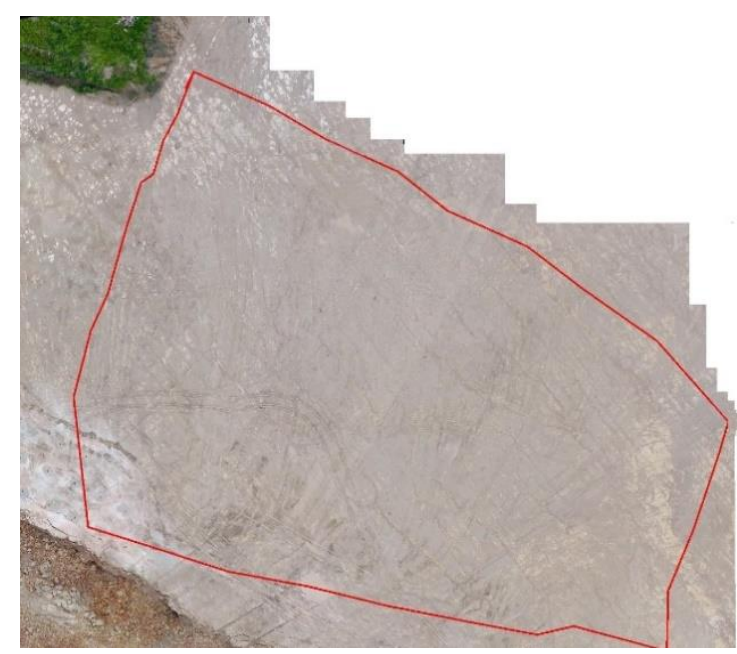

By use of "Virtual Surveyor"

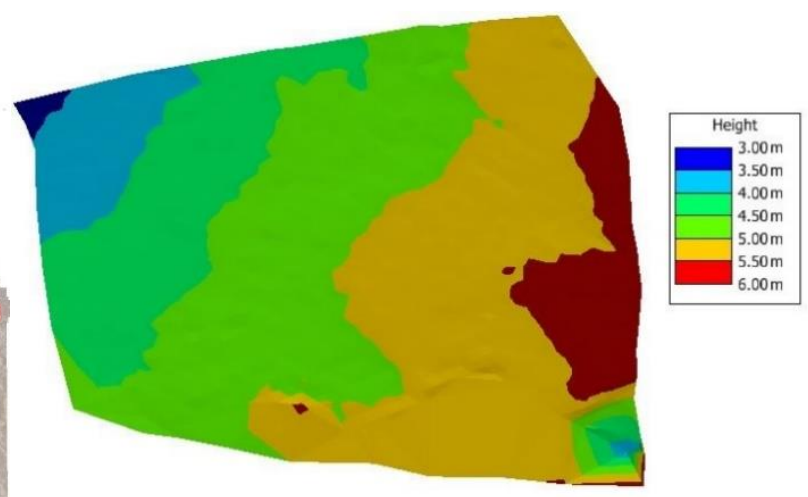

By use of "Bentley PowerSurveyV8i"

Fig. 3. Surface model according to DJI Phantom4 data in July 2018.

In October and December 2018, second and third stage of measurement of the quarry was organized, by use of three measurement methods. According to measurement data, surface models for the territory of the quarry in software environment "Virtual Survey" and "Bentley Microstation Powersurvey V8i" were obtained. Possibility to carry out visual comparison of the created models arose. For example, if we 
compare the created models according to data of tachymetric measurement method in October, the model that is developed by "Bentley PowerSurveyV8i" (Fig.4) is better perceptible visually than the model developed by the other geospatial program.

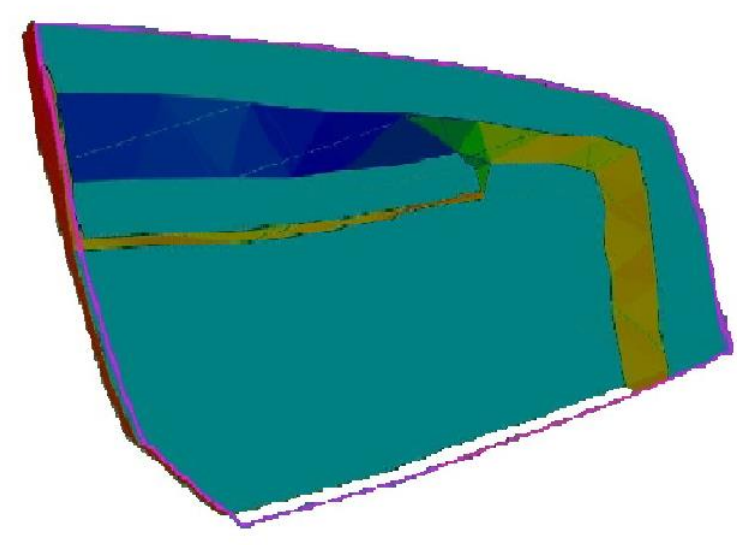

By use of "Virtual Surveyor"

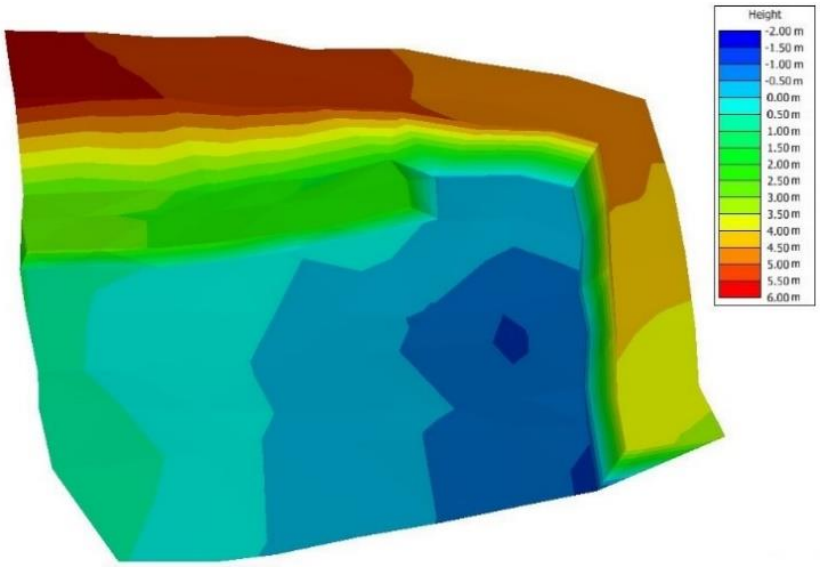

By use of "Bentley PowerSurveyV8i"

Fig. 4. Surface model according to data of tachymetric measurement in October 2018.

In the surface model according to "Virtual Surveyor", detailing in even planes is smaller. Nevertheless, regardless of the data visualization usage of both programs ensures full-fledged numerical file that enables calculations of various types.

As from July extraction of the useful mineral - dolomite was performed, the extracted volumes were calculated according to surface models created by measurement data. Calculations of volumes of extraction of useful minerals were carried out by use of the surface models obtained. In each program of processing of geospatial data, identical data ( $\mathrm{x}, \mathrm{y}$ and $\mathrm{z}$ coordinates), which were obtained in each stage of measurement, were placed. Thus the obtained results are mutually comparable and can be analyzed. Calculations of extracted useful volumes and their differences between measurement stages are summarized in Table 2.

Table 2

Calculations of extracted useful volumes and their differences between measurement stages

\begin{tabular}{|c|c|c|c|c|c|c|}
\hline \multirow{2}{*}{$\begin{array}{l}\text { Measurement } \\
\text { method }\end{array}$} & \multicolumn{2}{|c|}{$\begin{array}{c}\text { Calculation of } \\
\text { values by } \\
\text { "Virtual Surveyor" } \\
\left(\mathbf{m}^{\mathbf{3}}\right)\end{array}$} & \multicolumn{2}{|c|}{$\begin{array}{c}\text { Calculation of values } \\
\text { by "Bentley } \\
\text { PowerSurvey V8i" } \\
\left(\mathrm{m}^{3}\right)\end{array}$} & \multicolumn{2}{|c|}{$\begin{array}{c}\text { Differences of } \\
\text { extracted volumes } \\
\left(\mathbf{m}^{3}\right)\end{array}$} \\
\hline & $\begin{array}{l}\text { July } \\
\text { October }\end{array}$ & $\begin{array}{l}\text { October } \\
\text { December }\end{array}$ & $\begin{array}{l}\text { July } \\
\text { October }\end{array}$ & $\begin{array}{l}\text { October } \\
\text { December }\end{array}$ & $\begin{array}{l}\text { July } \\
\text { October }\end{array}$ & $\begin{array}{l}\text { October } \\
\text { December }\end{array}$ \\
\hline $\begin{array}{l}\text { Tachymetric } \\
\text { measurement } \\
\text { method }\end{array}$ & 19555 & 3948 & 19473 & 3805 & 82 & 143 \\
\hline $\begin{array}{l}\text { GNSS positioning } \\
\text { method }\end{array}$ & 19712 & 3924 & 19614 & 3792 & 98 & 132 \\
\hline $\begin{array}{l}\text { Remote sensing } \\
\text { method }\end{array}$ & 18835 & 3654 & 18663 & 3611 & 172 & 43 \\
\hline
\end{tabular}

If we analyze the obtained results, we can see differences of extracted volumes between measurement methods. Differences of extracted volumes according to tachymetric measurement method for period October-December are greater than for period July - October. Such tendency could be observed for differences of volumes of extraction of GNSS positioning measurement data. This can be explained with factor that in the first stage of measurement in July active extraction in the quarry was not started. 
Therefore, the surface to be measured in July was even, without sharp forms of relief. In measurements of October and December, the surface to be measured was after performed rock blasting works for the extraction of dolomite. Therefore, measurement of the relief by use of Tachymetric and GNSS Positioning Method is challenge for very uneven surface covered by dolomite debris. It is difficult to measure from $4 \mathrm{~m}$ up to $8 \mathrm{~m}$ wide parts of blasted dolomite.

Differences of extracted volumes according to Remote Sensing Method in period July - October are fore times greater than in period October - December. It is possible that it is related to effects of some type in the measurement process. In the Remote Sensing Measurement Method, unmanned aircraft in the course of flight fixes images on the entire situation in the terrain, and in surface model, information also on blasted parts of dolomite appears.

As the research was developed, we can see that accounting of extraction of useful minerals is possible by use of different geodetic measurement methods. Each of methods has different preparation, measurement and field data processing processes. Therefore, as work performer carries out measurements, it is possible to obtain measurement product by use of measurement and data processing methods and programs of different type. It is important that as measurement procedure is carried out, control procedure is ensured, thus it is ensured that credibility of the end product is as high as possible. As accuracy of measurements in the Tachymetric Measurement Method was analyzed, it was not worse than $5 \mathrm{~mm}$. Accuracy of GNSS measurements was not worse than $1 \mathrm{~cm}$. Accuracy of measurements of remote sensing was not worse than $5 \mathrm{~cm}$. If we take into account the exactness of results of measurements, we can see the differences of obtained volumes of surface models in "Virtual Survey" and "Bentley Microstation Powersurvey V8i" program environment. As input data in both program environments were identic, results show that volumes of useful minerals are greater in "Virtual Surveyor" program environment. We can see that the factor that affects the volume of the useful minerals is the structure of the algorithm of the used programs, which ensures the corresponding value.

\section{Conclusions and proposals}

1. Tachymetric measurement method can be used under any circumstances and in any terrain situation, where surveyor with equipment has access. The method does not depend on terrain circumstances, GNSS visibility, GSM communication system coverage.

2. GNSS positioning method can be used full-fledgedly at "open horizon" and perfect GSM communication system coverage.

3. Usage of remote sensing method ensures obtaining of homogenous surface model. Important factors of the measurement method are climatic circumstances and surveyors experience.

4. Results show that the selected measurement method is the main factor affecting the accuracy the depiction of useful minerals, surface of quarries.

5. Differences of values of volumes of useful minerals between "Virtual Survey" and "Bentley Microstation Powersurvey V8i" do not exceed 5\%. The obtained results of the study show, that in calculations of volumes both program packages shall be used, as it is prescribed in Regulations of the Cabinet of Ministers of the Republic of Latvia No. 570, on "Procedure of extraction of useful minerals".

6. For the calculation of volume of useful minerals, measurement method with the highest accuracy that can be achieved shall be applied by use of corresponding technical equipment and data processing software. In the measurement process, control mechanism of the obtained results shall be ensured.

\section{References}

1. Augstas detalizāaijas topogrāfiskās informācijas un tās centrālās datubāzes noteikumi (Regulations on topographic information of high detail and its central database): 24.04.2012. Regulations of Minister Cabinet No.281. Viewed 18 February, 2020, (https://likumi.lv/doc.php?id=246998) (In Latvian)

2. Bosas, G., Kaupas, A., Jonikavičius, D., Mozgeris, G. 2013. Aeronuotrauka naudojant bepiloti orlaivị - 3D objektų tūrio nustatymo tikslumas, In: conference proceedings, Matavimų inžinerija ir GIS: Respublikinè mokslinè-praktinè konferencija, Kaunas, pp. 30-35.

3. Derīgo izraktenu ieguves kārtība (Procedure of extraction of useful minerals): 21.08.2012. Regulations of Minister Cabinet No.570. Viewed 17 February, 2020, (https://likumi.lv/doc.php?id=251021) (In Latvian) 
4. Digitālā virsmas model̦a veidošana ar Bentley PowerSurvey [Creating a digital surface model with Bentley PowerSurvey] (2014): Mikrokods editorial board. Riga: Mikrokods. 34 p. (In Latvian)

5. Gueodēziskās atskaites sistēmas un topogrāfisko karšu sistēmas noteikumi (Regulation of geodetic reference system and topographic map system): 15.11.2011. Regulations of Minister Cabinet No.879. Viewed 7 March, 2020, (https://likumi.lv/doc.php?id=239759) (In Latvian)

6. Jawecki, B., Szewran'ski, S., Stodolak, R., Wang ZhaoLong (2019) The use of digital terrain models to estimate the pace of filling the pit of a central European granite quarry with water, By:, Water, 20734441, , Vol. 11, Issue 11, DOI:10.3390/w11112298

7. Kalantaite A., Putrimas R., Šlikas D. (2010) Erdviniu skenavimo duomenų taikymas vietoves trimačiams modeliams generuoti, In: Geodezija ir kartografija. VGTU, 36 (4), pp. 151-155.

8. Kubodera, T.; Suzuki, T.; Masaharu, H.; Matsuo, E. (2017) Analysis on Surface Deformation and Cracks in Paddy Fields by 2016 Kumamoto Earthquake using GNSS and Photogrammetry, International Journal of Environmental and Rural Development 8 (1) Tokyo: International Society of Environmental and Rural Development, pp. 85-92.

9. Lukss I. (2017) Realitātes 3 d modelēšana un tās pielietojumi [Reality $3 \mathrm{~d}$ modeling and its applications], LU 75. scientific conference, section "Geomatics”. Viewed 30 March, 2020, (https://www.geo.lu.lv/fileadmin/user_upload/lu_portal/projekti/gzzf/Konferences/03_3D_modelesana_Luks s_2017.pdf) (In Latvian)

10. Luukkonen T. (2011) Modelling and control of quadcopter, Espoo, Aalto University, $26 \mathrm{p}$

11. Matos J., Goncalves A. (2003) Measurment and analysis of positional accuracy, In: Geodezija ir kartogrāfija, VGTU, Vol. 29 (1), ISSN 1392-1541, pp. 20-26.

12. Noteikumi par valsts nozīmes derīgo izrakteņu atradnēm (Regulations regarding mineral deposits of national significance): 08.05.2012. Regulations of Minister Cabinet No.321. Viewed 10 July, 2018, (https://likumi.lv/doc.php?id=247498) (In Latvian)

Information about authors:

Armands Celms Dr.sc.ing, professor of Department of Land Management and Geodesy at Latvia University of Life Sciences and Tehcnologies, Akademijas iela 19, Jelgava, LV-3001, armands.celms@1lu.1v

Vivita Pukīte Dr.oec., professor of Department of Land Management and Geodesy at Latvia University of Life Sciences and Tehcnologies, Akademijas iela 19, Jelgava, LV-3001, vivita.pukite@1lu.lv

Ilona Reke Mg.sc.ing, doctoral student of Department of Land Management and Geodesy at Latvia University of Life Sciences and Tehcnologies, Akademijas iela 19, Jelgava, LV-3001, ilona.reke@ gmail.com

Giedrius Balevičius Mg.sc.ing., lecturer of Institute of Land Management and Geomatics at Vytautas Magnus University Agriculture Academy, Studentų str. 11, LT-53361 Akademija, Kauno r., giedrius.balevicius@vdu.lt Sandija Ozolina Land surveyor "Metrum” Ltd., sandijaozolina@ gmail.com 